10. Tіханков I. O. Показники росту, як критерії оцінки гетеробластії дерноутворюючих трав. Науковий вісник Ужгородського університету. Серія Біологія. 2008. Вып. 24. C. $227-233$.

11. Федотова Ю. К. К вопросу о содержании основных пигментов фотосинтетического аппарата у Geranium sanguineum флоры центрального Предкавказья. Вестник МГОУ. Серия Естественные науки. 2009. № 1. С. 81-84.

12. Dias-Filho M. B. Growth and biomass allocation of the $\mathrm{C}_{4}$ grasses Brachiaria brizantha and B. humidicola under shade. Pesq. Agropec. Bras. 2000. Vol. 35. № 12. P. 2335-2341.

13. Hunt $\boldsymbol{W} . \boldsymbol{F}$. Fifty years of ryegrass research in New Zealand. Proceedings N.Z. grassland association. 1989. Vol. 50. P. 11-23.

14. Hunt W. F., Field T. R. Growth characteristics of perennial ryegrass. Proceedings N.Z. grassland association. 1979. Vol. 40. P. 104-113.

15. Registration of Repell II perennial ryegrass. R. H. Hurley, V. G. Lehman, D. C. Funk, C. R. Funk Crop. Science. 1994. Vol. 34. № 5. P. 1409-1410.

16. Index of species information. Spicies: Lolium perenne. URL: https://www.fs.fed. us/database/feis/plants/graminoid/lolper/all.html (last access: 10.09.17). Index of species information.

17. Kays S., Harper $\boldsymbol{J}$. L. The regulation of plant and tiller density in a grass sword J. Ecology. 1974. Vol. 62, № 1. P. 97-105.

18. Ort D. $R$. When there is too much light. Plant Physiology. 2001.Vol. 125. P. $29-32$.

19. Perennial ryegrass management - grazing management to maximise growth and nutritive value. URL: https://www.dairyaustralia.com.au/farm/feedbase-and-animal-nutrition/ pasture/perennial-ryegrass-management

20. Woledge $\boldsymbol{J}$. The effect of light intensity during growth on the subsequent rate of photosynthesis of leaves of tall fescue (Festuca arundinacea Schreb.). Ann. Bot. 1971. Vol. 35. № 2. P. 311-322.

Надійшла до редколегії 1.10.2017 p.

В. М. Зверковський, В. Д. Калько

Дніпровський національний університет імені Олеся Гончара

\title{
КОНСТРУЮВАННЯ РЕКУЛЬТИВАЦЙНОГО ШАРУ НА ПОРУШЕНИХ ЗЕМЛЯХ ЗАХІДНОГО ДОНБАСУ
}

Досліджено фізико-хімічні та агрохімічні показники шахтних порід і штучних грунтів ділянки рекультивації на порушених землях шахти «Тернівська». Встановлено властивості і показники субстратів рекультиваційного шару, що впливають на лісопридатність і формують специфічний тип лісорослинних умов на штучних грунтах ділянки рекультивації.

Ключові слова: рекультивація, шахтна порода, штучні грунти, фізико-хімічні властивості, ступінь лісопридатності.

\section{В. Н. Зверковский, В. Д. Калько \\ Днепровский национальный университет имени Олеся Гончара \\ КОНСТРУИРОВАНИЕ РЕКУЛЬТИВАЦИОННОГО СЛОЯ НА НАРУШЕНННЫХ ЗЕМЛЯХ ЗАПАДНОГО ДОНБАСА}

Исследованы физико-химические и агрохимические свойства шахтных пород и искусственных почво-грунтов участка рекультивации на нарушенных землях шахты «Терновской». Определены свойства и показатели субстратов рекультива-

(C) В. М. Зверковський, В. Д. Калько, 2017 
ционного слоя, которые влияют на их лесопригодность и формируют специфический тип лесорастительных условий на искусственных почво-грунтах участка рекультивации.

Ключевые слова: рекультивация, шахтная порода, искусственные почво-грунты, физико-химические свойства, степень лесопригодности.

\author{
V. M. Zverkovsky, V. D. Kalko \\ Oles Honchar Dnipro National University
}

\title{
CONSTRUCTION OF A RECLAMATION LAYER ON DISTURBED LANDS OF THE WESTERN DONBAS
}

The physical-chemical and agrochemical indices of mine rocks and artificial soils of reclamation areas on disturbed lands of mines «Ternovskaya» are investigated.

The properties and indices of the substrates of the reclamation layer, which influence the forest suitability and form a specific type of forest vegetation conditions on artificial soils of the reclamation sites, are established.

In accordance with the development of the O. Honchar Dnipro National Univesity on the rational structures of the reclamation layer in 2017 , the technical reclamation of land affected by mining operations of the Ternovskaya mine in Ternivka, Dnipropetrovsk region was completed. As a result of mining, there was a subsidence of the earth's surface in the southern part of the town of Ternivka and the floodplains of the Samara and Ternovka rivers.

On the flooded as a result of man-made settling of the territory, the total area of 120,67 hectares is at the height of the total size of the subsidence on which a recultivating layer is formed from potentially woodland rocks.

Keywords: recultivation, reclamation, mine rock, artificial soil, physico-chemical properties, grades of forest suitability.

Докорінна меліорація поверхні промислових відвалів у Західному Донбасі проводиться шляхом землювання. На плоских породних відвалах формуються різні варіанти насипних штучних грунтів, які враховують вимоги біологічного етапу лісової рекультивації до технічного періоду, коли формується рекультиваційний шар. Конструкції штучних едафотопів мають враховувати фізико-хімічні властивості шахтних порід, як і потенційно родючих порід рекультиваційного шару, а також техніко-економічні умови, або реальні можливості рекультивації, що мають місцевий (часто відомчий) характер.

Виконані нами дослідження дали можливість розробити та здійснити заходи зниження негативного впливу гірничих робіт на земну поверхню на гірничих відводах шахтоуправління «Павлоградське». Вони є одним із елементів регіональної програми охорони навколишнього середовища на території Павлоградського району Дніпропетровської області.

Створення лісових угруповань в умовах явної екологічної невідповідності між рослинністю та середовищем існування може досягти успіху в адаптації $\mathrm{i}$ сильватизації компонентів лише за умови правильної конструкції лісових насаджень. При цьому необхідно використовувати типологію О. Л. Бельгарда [2] за урахуванням:

1. Типу лісорослинних умов.

2. Типу екологічної структури.

3. Типу деревостану.

На ділянках лісової рекультивації ці таксономічні показники є значною мірою динамічними і водночас більш керованими у порівнянні із штучними насадженнями степової зони на непорушених землях.

Тип лісорослинних умов залежить від ступеня мінералізації грунтового розчину (що визначає рівень родючості) і від градації зволоження. На ділянках ре- 
культивації промислових відвалів пустої шахтної породи лісорослинні умови залежать у першу чергу від конструкції рекультиваційного шару $[2 ; 4 ; 10]$.

Відповідно до розробок ДНУ імені Олеся Гончара про раціональні конструкції рекультиваційного шару [4; 5], у 2017 р. завершено технічну рекультивацію земель, порушених гірничими роботами шахти «Тернівська» в м. Тернівка Дніпропетровської області. В результаті ведення гірничих робіт відбулося осідання земної поверхні в південній частині міста Тернівка і заплавах річок Самари і Тернівки. На затопленій внаслідок техногенного осідання території було відсипано шахтними породами і відходами збагачувальної фабрики плоский породний відвал загальною площею 120,67 га на висоту сумарної величини осідання, на якому сформовано рекультиваційний шар із потенційно лісопридатних порід. Порушені землі межують із запроектованим ландшафтним заказником місцевого значення «Богуславський».

Ділянка рекультивації загальною площею 120,67 га поділяється на 3 частини залежно від термінів закінчення підземних гірничих робіт. Перша ділянка площею 57,54 га розміщена у південній і південно-східній частині порушеної території. Друга ділянка розміщена у північній та східній частинах порушеної території, iіi площа 46,58 га. Третя ділянка площею 16,55 га знаходиться у західній частині порушених земель (рис. 1). Тут розробка вугільних пластів закінчена у 2016 році.

Згідно з Проектом, біологічний етап рекультивації повинен забезпечити використання ділянок під продуктивне пасовище (з використанням рослин-медоносів) та під зелені зони [6].

У картографічних матеріалах Робочого проекту (М 1:500, рис.1) ці зелені зони, що плануються під створення полезахисних лісосмуг, розміщують по контурах кожної з трьох ділянок, тобто ділянки розмежовуються лісосмугами; ширина таких лісосмуг варіює від 15 м (ділянка № 3) до 60 м (на межі ділянок 1 і 2). Загальна довжина лісосмуг становить 5,18 км.

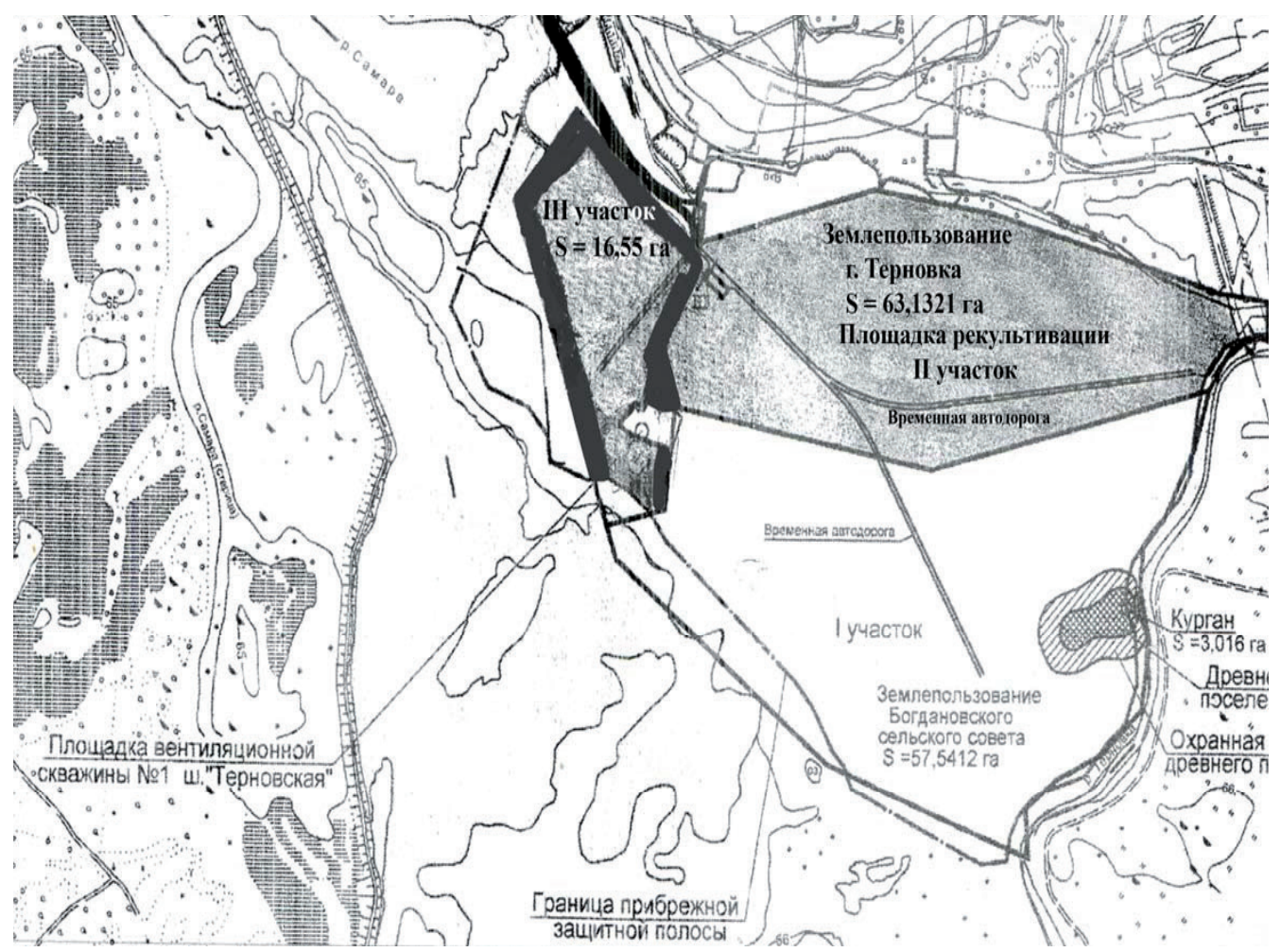

Рис. 1. Ситуаційний план району дослідження 
На площах, де завершено технічний етап рекультивації, у межах запланованого розміщення лісосмуг, на трьох окремих ділянках було закладено грунтові розрізи (всього 3). Описано морфологічну будову грунтового профілю. Відібрано по 2 зразки грунту з кожного виділеного горизонту для фізико-хімічного аналізу (всього 24 зразка, табл. 1).

Рельєф поверхні ділянки переважно рівнинний. Лише поблизу південного краю ділянки у мезорельєфі з'являються невеликі підвищення (гребні), що межують із западинами глибиною до 0,5 м. Виражене самозаростання трав'янистою рослинністю, що не утворює суцільного покриття.

На ділянці № 1 і 3 із гумусованим супіском розріджений травостій висотою до 90 см; на ділянці № 2, де на поверхні щільна і в’язка червоно-бура глина, травостій висотою до 60 см; на ділянці № 3 із більш гумусованим супіском травостій місцями густий, висотою до 140 см. Супіски ділянок № 1, № 3 - пістряві, 3 механічними домішками темно-жовтого кольору (іноді оглеєного) або палево-бурого піску. Тут скипання від дії 10 \% $\mathrm{HCl}$ фрагментарне, якраз на виходах піску; безструктурна червоно-бура глина ділянки номер 2 показує бурхливе скипання, що свідчить про наявність $\mathrm{CaCO}_{3}$.

Таблиия 1

Зразки штучних грунтів рекультиваційного шару на відвалі шахти «Тернівська»

\begin{tabular}{|c|c|c|}
\hline № & Глибина відбору, см & Гранулометричний склад \\
\hline Розріз № 1 & \multicolumn{2}{|c|}{} \\
\hline 1 & $0-11$ & Гумусований супісок \\
\hline 2 & $11-26$ & Гумусований супісок \\
\hline 3 & $26-46$ & Гумусований супісок \\
\hline 4 & $46-54$ & Гумусований супісок \\
\hline 5 & $54-600$ & Суглиниста шахтна порода \\
\hline Розріз № 2 & $0-8$ & Важка глина \\
\hline 1 & $8-29$ & Важка глина \\
\hline 2 & $29-43$ & Важка глина \\
\hline 3 & $43-600$ & Суглиниста шахтна порода \\
\hline 4 & $0-17$ & Темно-сірий пісок \\
\hline Розріз № 3 & $17-64$ & Темно-жовтий пісок \\
\hline 1 & $64-600$ & Суглиниста шахтна порода \\
\hline 2 & \multicolumn{2}{|c|}{}
\end{tabular}

В лабораторних умовах досліджено показники: об'ємної і питомої ваги, порозності, вміст гігроскопічної вологи, максимальна гігроскопічна волога, вологість зів'янення, вміст сухого залишку (ступінь засолення), склад водорозчинних сполук, агрохімічний аналіз $[1 ; 3 ; 7 ; 8]$.

Надмірно високі показники вмісту недоступної для рослин вологи (до 8,4 \%) відрізняють суглинки і глини ділянки № 2; рекультиваційний шар ділянок № 1 i № 3 сформовано супісками, і тут вміст недоступної вологи значно менший, лише в окремих горизонтах він досягає $4,77 \%$.

Показники порозності також залишаються незадовільними у глинах ділянки № 2 (не більше 17,9 \%); в супісках ділянок № 1 і № 3 порозність досягає 31,3 \%, наближаючись до оптимальних значень (35-38 \%).

Вміст сухого залишку (кількість водорозчинних солей у насипних грунтах) свідчить про відсутність засолення, але підстилаючі шахтні породи фрагментарно досягають надмірних значень вмісту солей $(0,34$ \% у розрізі № 2 , середній ступінь засолення, табл. 2, 3, 4). 
Отже, більшість проаналізованих проб штучних грунтів не має ознак суттєвого засолення, про що свідчать саме визначені величини сухого залишку. Привертає увагу більш значна кількість солей у зразках № 3 та № 4 (ділянка № 2; табл. 3), яка свідчить про незначне чи середнє засолення. Саме ці зразки були більш детально розглянуті. Використовуючи таблиці з посібника [8], було визначено, що зразок № 3 має хлоридно-сульфатне засолення, а за співвідно-шенням катіонів - магнієво-кальцієвий тип. Зразок № 4 має сульфатне засолення і кальцієво-натрієвий тип.

Таблиия 2

Водорозчинні сполуки насипних грунтів на ділянках рекультивації, розріз № 1

\begin{tabular}{|c|c|c|c|c|c|c|c|c|c|c|c|c|c|c|c|c|c|}
\hline \multirow[b]{3}{*}{ 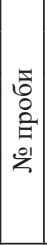 } & \multirow[b]{3}{*}{ 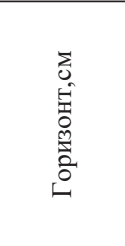 } & \multirow[b]{3}{*}{$\mathrm{pH}$} & \multicolumn{6}{|c|}{ Аніони } & \multicolumn{8}{|c|}{ Катіони } & \multirow{3}{*}{ 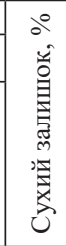 } \\
\hline & & & \multicolumn{2}{|c|}{$\mathrm{HCO}_{3}^{-}$} & \multicolumn{2}{|c|}{$\mathrm{Cl}^{-}$} & \multicolumn{2}{|c|}{$\mathrm{SO}_{4}^{2-}$} & \multicolumn{2}{|c|}{$\mathrm{Ca}^{2+}$} & \multicolumn{2}{|c|}{$\mathrm{Mg}^{2+}$} & \multicolumn{2}{|c|}{$\mathrm{Na}^{+}$} & \multicolumn{2}{|c|}{$\mathrm{K}^{+}$} & \\
\hline & & & 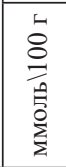 & $a^{\circ}$ & 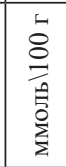 & $a^{\circ}$ & 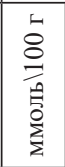 & $a^{\circ}$ & 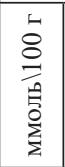 & $a^{\circ}$ & 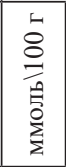 & $0^{\circ}$ & 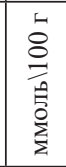 & $a^{\circ}$ & 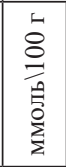 & $a^{\circ}$ & \\
\hline 1 & $\mathrm{H}_{1}: 0-11$ & 8,00 & 0,50 & 0,031 & 0,05 & 0,002 & 0,07 & 0,003 & 0,30 & 0,006 & 0,18 & 0,002 & 0,08 & 0,002 & 0,05 & 0,002 & 0,04 \\
\hline 2 & $\mathrm{H}_{2}: 11-26$ & 7,64 & 0,55 & 0,034 & 0,07 & 0,002 & 0,25 & 0,012 & 0,44 & 0,009 & 0,30 & 0,004 & 0,09 & 0,002 & 0,08 & 0,003 & 0,06 \\
\hline 3 & $: 26-46$ & 7,77 & 0,55 & 0,034 & 0,06 & 0,002 & 0,21 & 0,010 & 0,30 & 0,006 & 0,08 & 0,001 & 0,45 & 0,010 & 0,17 & 0,009 & 0,08 \\
\hline 4 & $\mathrm{H}_{4}: 46-54$ & 7,75 & 0,60 & 0,037 & 0,05 & 0,002 & 0,18 & 0,009 & 0,60 & 0,012 & 0,06 & 0,001 & 0,16 & 0,004 & 0,09 & 0,003 & 0,06 \\
\hline 5 & $\mathrm{P}_{2}: 54-600$ & 7,77 & 0,40 & 0,024 & 0,05 & 0,002 & 0,32 & 0,015 & 0,60 & 0,012 & 0,04 & 0,001 & 0,08 & 0,002 & 0,06 & 0,002 & 0,07 \\
\hline
\end{tabular}

Таблиия 3

Водорозчинні сполуки насипних грунтів на ділянках рекультивації, розріз № 2

\begin{tabular}{|c|c|c|c|c|c|c|c|c|c|c|c|c|c|c|c|c|c|}
\hline \multirow[b]{3}{*}{$\begin{array}{l}\text { 吉 } \\
0 \\
0 \\
\vdots \\
\text { 익 }\end{array}$} & \multirow{3}{*}{ 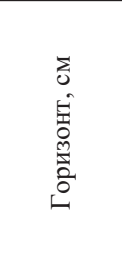 } & \multirow[b]{3}{*}{$\mathrm{pH}$} & \multicolumn{6}{|c|}{ Аніони } & \multicolumn{8}{|c|}{ Катіони } & \multirow{3}{*}{ 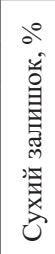 } \\
\hline & & & \multicolumn{2}{|c|}{$\mathrm{HCO}_{3}^{-}$} & \multicolumn{2}{|c|}{$\mathrm{Cl}^{-}$} & \multicolumn{2}{|c|}{$\mathrm{SO}_{4}^{2-}$} & \multicolumn{2}{|c|}{$\mathrm{Ca}^{2+}$} & \multicolumn{2}{|c|}{$\mathrm{Mg}^{2+}$} & \multicolumn{2}{|c|}{$\mathrm{Na}^{+}$} & \multicolumn{2}{|c|}{$\mathrm{K}^{+}$} & \\
\hline & & & $\frac{b}{8}$ & $a^{0}$ & $\begin{array}{l}\frac{5}{8} \\
\frac{8}{0} \\
\frac{0}{0} \\
\sum_{i}^{0}\end{array}$ & $0^{\circ}$ & $\begin{array}{l}\stackrel{5}{8} \\
\stackrel{1}{1} \\
\frac{0}{3}\end{array}$ & $0^{\circ}$ & $\frac{b}{8}$ & $0^{\circ}$ & $\begin{array}{l}\stackrel{5}{8} \\
\frac{8}{8} \\
\frac{1}{0} \\
\sum_{i}^{0}\end{array}$ & $a^{0}$ & $\begin{array}{l}\frac{5}{8} \\
\frac{8}{0} \\
\frac{0}{0} \\
\frac{0}{\Sigma}\end{array}$ & $a^{0}$ & $\begin{array}{l}5 \\
\frac{5}{8} \\
\frac{1}{0} \\
\frac{0}{5} \\
\sum_{\Sigma}\end{array}$ & $d^{0}$ & \\
\hline 1 & $\mathrm{hP}_{1}: 0-8$ & 7,75 & 0,60 & 0,037 & 0,05 & 0,002 & 0,11 & 0,005 & 0,40 & 0,008 & 0,20 & 0,002 & 0,11 & 0,003 & 0,07 & 0,003 & 0,06 \\
\hline 2 & $\mathrm{P}_{2}: 8-29$ & 7,95 & 0,65 & 0,040 & 0,05 & 0,002 & 0,18 & 0,009 & 0,60 & 0,012 & 0,18 & 0,002 & 0,15 & 0,003 & 0,08 & 0,004 & 0,07 \\
\hline 3 & $\mathrm{P}_{3}: 29-43$ & 8,45 & 0,80 & 0,049 & 0,10 & 0,004 & 0,45 & 0,022 & 0,80 & 0,016 & 0,31 & 0,004 & 0,15 & 0,003 & 0,08 & 0,004 & 0,11 \\
\hline 4 & $\mathrm{P}_{4}: 43-600$ & 7,40 & 0,50 & 0,031 & 0,12 & 0,004 & 3,60 & 0,173 & 0,98 & 0,020 & 0,78 & 0,010 & 2,50 & 0,058 & 0,11 & 0,005 & 0,34 \\
\hline
\end{tabular}

Табличя 4

Водорозчинні сполуки насипних грунтів на ділянках рекультивації, розріз № 3

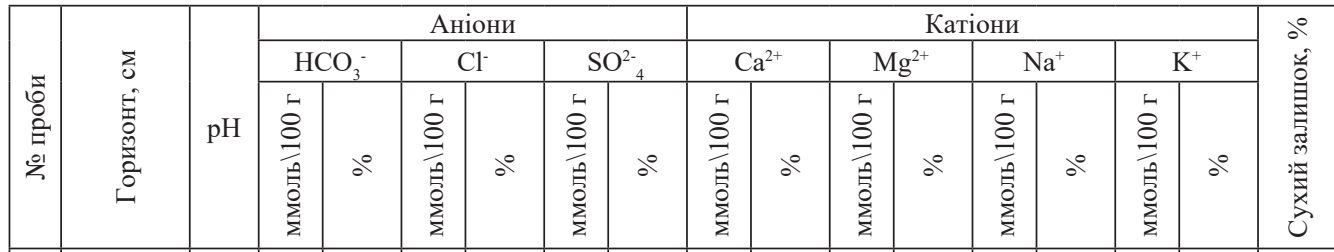

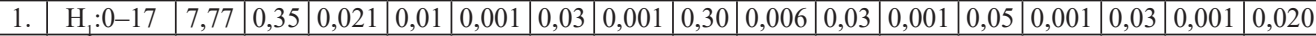

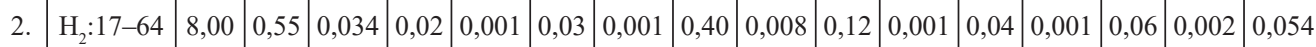

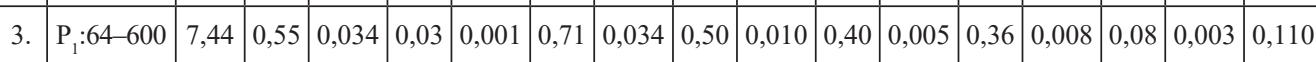

Використовуючи класифікацію грунтів залежно від типу їх засолення [8; 9], встановлено, що обидва зразки знаходяться у градації слабкозасоленого грунту. 
Із усіх зразків розрізу № 2 найбільш солоний зразок № 4 (табл. № 3). Зразок № 3 межує 3 цим зразком, це суглинок, який перекриває породу. Його мінералізація значно перевищує показники вище розміщених глинистих субстратів. Очевидно, що підвищена солоність зразка № 3 зумовлена міграцією водорозчинних солей із шахтної породи. Встановлено, що загальна кількість токсичних солей зразка № 3 незначна (0,325 ммоль $\backslash 100$ г), а у зразка № 4 - 5,31 ммоль \100 г, що говорить про рівень засолення, близький до середнього.

Виконані агрохімічні дослідження грунтів рекультиваційного шару свідчать, що верхні горизонти мають $\mathrm{pH}$, близьке до нейтрального, фрагментарно спостерігається слабко- і середньолужна реакція ( $\mathrm{pH}$ до 8,4). Вміст гумусу у верхніх горизонтах досягає 4,31 \% (ділянка № 2, горизонт 0-8 см). Нижче розміщені горизонти з низьким вмістом гумусу - менше $2 \%$. В усіх розрізах і горизонтах забезпеченість доступними формами азоту, фосфору, калію низька $\mathrm{i}$ дуже низька [3].

Одержані фізико-хімічні та агрохімічні показники рекультиваційного шару свідчать, що для створення захисних лісосмуг, запланованих для біологічної рекультивації, слід підбирати лише оліготрофні екоморфи [2], застосовуючи маловимогливі до родючості деревні і чагарникові породи. На глинистих субстратах (ділянка № 2) їх склад обмежується жорсткими водно-фізичними показниками і помірним засоленням штучних грунтів рекультиваційного шару.

\section{Бібліографічні посилання}

1. Аринуикина E. В. Руководство по химическому анализу почв. Москва: МГУ, 1970. $488 \mathrm{c}$.

2. Бельгард А. Л. Степное лесоведение. Москва: Наука. 1971. 336 с.

3. Господаренко Г. М. Агрохімія: підручник. Київ: ННЦ «ІАЕ». 2010. 400 с.

4. Зверковский В. Н. Особенности развития лесных насаждений в многолетнем эксперименте по рекультивации отвала шахты «Павлоградская». Питання степового лісознавства та лісової рекультивації земель: Зб. наук. працьь. Дніпропетровськ: ДНУ. 2002. C. 21-30.

5. Зверковський В. М., Романова Н.В., Молдован М.С. Хімічні властивості шахтних порід Західного Донбасу. Питання степового лісознавства та лісової рекультиваиії земель. Зб. наук. праць. 2008. Вип. 12 (37). С. 6.

6. Мицик Л. П., Лихолат Ю. В. Дерновий покрив техногенних територій. Д.: ДДУ, 1997. $92 \mathrm{c}$.

7. Панкова Е. И., Базилевич Н.И. Методические указания по учету засоленных почв Руководство. Гипроводхоз Москва, 1968. С. 89.

8. Руководство по составлению почвенно-мелиоративного обоснования проектов мелиоративного строительства и специальных карт. Москва: Союзвод-проект, 1973. $106 \mathrm{c}$.

9. Травлеев Л. П., Травлеев А.П. Спутник геоботаника по почвоведению и гидрологии. Днепропетровск: Изд-во ДГУ. 85 с. : ил. + 14 л. табл.

10. Травлеев А. П. Биоэкологические особенности охраны лесных биогеоценозов и лесной рекультивации техногенных ландшафтов Западного Донбасса. А. П. Травлеев, В. Н. Зверковский, Н. Н. Цветкова и др. 1989. С. 175-182.

Надійшла до редколегії 21.10.2017 p. 